\title{
Koronavirüs (Covid-19) Pandemisinde Başlıca Gelişmiş ve Gelişmekte Olan Ülkelerde Kriz Yönetiminin Değerlendirilmesi
}

\author{
Hasan GÜL ${ }^{1}$ ve Furkan ÇELEBİ ${ }^{2}$
}

\section{$\ddot{O}_{\mathrm{z}}$}

Bu çalışmanın amacı 11 Mart 2020 tarihi itibariyle Dünya Sağlık Örgütü tarafından pandemi yani küresel salgın olarak ilan edilen Yeni Tip Koronavirüs (Covid-19) hastalığına ilişkin Başlıca Gelişmiş Ülkelerin (İtalya, A.B.D., Birleşik Krallık, Japonya, Kanada, Fransa, Almanya) ve bazı Gelişmekte Olan Ülkelerin (Polonya, Türkiye, İran, Arjantin, Brezilya, Rusya, Malezya) kriz yönetim becerilerinin değerlendirilmesidir. Bu amaç doğrultusunda literatür 1şığında "Pandemide Kriz Yönetimi Kriterleri" oluşturulmuştur. Bu değerlendirme yöntemine göre ülkelerin krizin başlangıcından itibaren ilk 14 günlük süredeki krize yönelik eylem ve tedbirleri incelenmiş ve IMF ekonomik sınıflandırmasına göre kıyaslanması gerçekleştirilmiştir. Araştırmada belirlenen kapsama göre alınan kararlar ve erken uygulamalar kriz yönetiminde başarı kriteri olarak belirlenmiştir. Elde edilen sonuçlara göre Türkiye pandemide kriz yönetimini en iyi gerçekleştiren ülke olurken; Kanada, Fransa, Rusya ve Malezya ise son sırada yer almıştır. IMF sınıflandırması açısından bakıldığında ise Gelişmekte olan ülkelerin ortalaması Başlıca Gelişmiş Ülkelerden daha yüksek olarak hesaplanmıştır. İnsani Gelişme Endeksi açısından da buna paralel bir durum söz konusudur. İncelenen ülkeler bazında, ortalama olarak, gelişmekte olan ülkelerin başlıca gelişmiş yedi ülkeden daha başarılı kriz yönetimi gerçekleştirdiği sonucuna ulaşılmışır.

Anahtar Kelimeler: Koronavirüs, Covid-19, Kriz yönetimi, Başlıca gelişmiş ülkeler, Gelişmekte olan ülkeler

\section{Evaluation of Crisis Management in the Coronavirus (Covid-19) Pandemic, the Major} Advanced Economies and the Emerging and Developing Economies

\begin{abstract}
The purpose of this study is to evaluate the crisis management skills of major advanced economies (Italy, the USA, the UK, Japan, Canada, France, Germany) and some emerging and developing economies (Poland, Turkey, Iran, Argentina, Brazil, Russia, Malaysia) during Coronavirus (Covid-19) which was spread around the world and announced pandemic, that is to say a global disease by WHO on 11 March 2020. In line with this objective, "Crisis Management Criteria in Pandemic" was formed in the view of literature. In reference to this evaluation method, countries' approaches to crisis in the first 14 days beginning from the outbreak were examined and they were compared according to IMF economic classification. Within the scope of the study, the decisions to be taken and earlier applications are specified as success criterion in crisis management. According to the results, Turkey is the most successful country to practice crisis management in pandemic, while Canada, France, Russia and Malaysia were the least successful. Looking at the viewpoint of IMF classification, average of emerging and developing economies is calculated higher than the average of major advanced economies. A relevant result can be seen with regards to the Human Development Index. On the basis of inspected countries, averagely, it is precipitated that emerging and developing economies implemented more successful crisis management than seven major advanced economies.
\end{abstract}

Key Words: Coronavirus, Covid-19, crisis management, Major advanced economies, Emerging and developing economies

Atıf İçin / Please Cite As:

Gül, H. ve Çelebi, F. (2020). Koronavirüs (Covid-19) pandemisinde başlıca gelişmiş ve gelişmekte olan ülkelerde kriz yönetiminin değerlendirilmesi. Manas Sosyal Araștırmalar Dergisi, 9(3), 1703-1715.

Geliş Tarihi / Received Date: 13.04.2020

Kabul Tarihi / Accepted Date: 21.05.2020

\footnotetext{
1 Prof. Dr. - Ondokuz Mayıs Üniversitesi, İktisadi ve İdari Bilimler Fakültesi, hasan.gul@omu.edu.tr ORCID: 0000-0002-3720-5451

2 Dr. - Yozgat Bozok Üniversitesi, Sorgun Meslek Yüksekokulu, furkan.celebi@bozok.edu.tr ORCID: 0000-0002-6689-9878
} 


\section{Giriş}

İnsanların, hayvanların, kuşların, yarasaların, farelerin ve diğer birçok vahşi hayvanın solunum, gastrointestinal, karaciğer ve merkezi sinir sistemlerini etkileyen koronavirüsler (CoV'ler), insanları ve diğer omurgalı hayvanları birlikte enfekte eden bir virüs grubudur (Xu vd., 2020, s. 1). Koronavirüsler soğuk algınlığ olarak bilinen genellikle hafif akut solunum yolu hastalıklarına neden olan yaygin insan patojenleridir. Aralık 2019'un sonlarında birkaç yerel sağlık tesisi, Çin'in Hubei Eyaletine bağlı Wuhan şehrinde bir deniz ürünleri ve sslak hayvan toptancillğı pazarında pnömoni vakaları kümelerinin tespit edildiğini bildirmiştir (Zhu vd., 2020, s. 727; Acar, 2020, s. 8; T.C. Sağlık Bakanlığ1 Covid-19 Rehberi, 2020, s. 5; WHO, Coronavirus Disease (COVID-19) Outbrake, 2020). Aralık 2019'dan önce, sadece iki ek koronavirüs vakası insanlarda ciddi akut solunum yolu hastalıkları salgınlarına neden olmuştu: 2002'de şiddetli akut solunum sendromu koronavirüs (SARS-CoV) ve 2012'de Orta Doğu solunum sendromu koronavirüs (MERS-CoV) (Denis vd., 2020, https://rega.kuleuven.be). Bu virüs grubu hayvanlardan insanlara geçen koronavirüslerdir. Yeni virüs, SARS ve MERS gibi bilinen koronavirüslerden farklıdır, ancak ateş, öksürük ve nefes darlığı gibi benzer solunum hastalığı semptomlarını paylaşmaktadırlar (Men vd., 2020).

9 Ocak 2020'de Wuhan'da ortaya çıkan yeni koronavirüs viral pnömoni salgınının geçici adı resmi olarak 2019-nCoV şeklinde tanımlanmıştır (https://www.who.int/china/news/detail). Sonraki haftalarda virüs Çin içinde hızla yayılmış ve diğer ülkelerde de artan sayıda vakalar ortaya çıkmıştır. 10 Nisan 2020 tarihi itibariyle Dünya Sağlık Örgütü verilerine göre dünyadaki toplam vaka say1s1 1.439.516'ya ve toplam ölü sayıs1 85,711'e yükselmiştir. Hastalık, 11 Şubat 2020'de WHO (Dünya Sağlık Örgütü) tarafindan COVID-19, diğer bir ifadeyle "SARS-CoV-2" olarak adlandırılmıştır (https://www.who.int/dg/speeches/detail). SARS-CoV-2'nin neden olduğu hastalığa "koronavirüs hastalı̆g1 2019” (COVID-19) denir. Daha sonra, Çin'deki bir grup virolog SARS-CoV-2'nin insan koronavirüs 2019 (HCoV-19) olarak yeniden adlandırılmasını önermiş, bu tür bir adın virüsü SARSCoV'den ayırt edeceğini ve hastalığın WHO adı ile tutarlı olacağını ileri sürmüşlerdir (Denis vd., 2020: 8).

Çin Halk Cumhuriyeti Ulusal Sağlık Komisyonu tarafindan yayınlanan verilere göre, SARS-CoV-2 büyük olasılıkla vahşi yarasalardan insanlara bulaşmıştır ve yukarıdaki üç CoV'nin hepsi kişiden kişiye bulaşabilmektedir. SARS-CoV-2, SARS-CoV ile oldukça benzer bir gen ve davranış örüntüsünü paylaşmaktadır (Xu vd., 2020, s. 1-2; Wang, 2006; Cortegiani vd., 2020). Çin ve dünya çapında pandemiye dönüşen SARS-CoV-2'nin genel özellikleri aşağıdaki tablo'da özetlenmiştir (Xu vd., 2020, s. 2; Balboni, Battilani ve Prosperi, 2012, s. 1-8):

Tablo 1. SARS-CoV-2'nin Genel Özellikleri

\begin{tabular}{ll}
\hline İlk görüldüğ̈̈ yer & 7 Aralık 2019, Wuhan, Hubei \\
Patojen & SARS-CoV-2 \\
Virüs türü & RNA virüsü \\
Tür patojeni & $\beta$-koronavirüs \\
Patojenin toplam DNA dizisi uzunluğu & 29903 \\
Hassas insanlar & SARS-CoV'ye maruz kalmayan insanlar \\
Ortaya çıkma süresi & Ortalama 3-7 gün \\
Erkek-kadın hasta oranı & $2.70: 1$ \\
Ölüm oranı & $\%$ 2.10 \\
Klinik semptomlar & Ateş, yorgunluk ve kuru öksürük \\
Yayılma modu & Damlacıklar veya yakın temas \\
Büyük bölgesel dağıtım & Hubei, özellikle Çin'deki Wuhan \\
Tanı yöntemleri & RT-PCR, rRT-PCR, RT-LAMP, rRT-LAMP, Koronavirüs tespit kiti \\
Tedavi & Lopinavir / ritonavir (testte) \\
\hline
\end{tabular}

Korona virüs, insanlar, diğer memeliler ve kuşlar arasında yaygın olarak dağılan ve solunum, enterik, hepatik ve nörolojik hastalıklara neden olan zarflı RNA virüsleridir. Altı koronavirüs türünün insan hastalı̆̆ına neden olduğu bilinmektedir. Dört virüs - 229E, OC43, NL63 ve HKU1 - yaygındır ve tipik olarak immünokompetan bireylerde yaygın soğuk algınlığı semptomlarına neden olmaktadır. Diğer iki tür şiddetli akut solunum sendromu koronavirüs (SARS-CoV) ve Ortadoğu solunum sendromu koronavirüs (MERS-CoV) - zoonotiktir ve ölümcül hastalıklara yol açabilmektedir (Zhu vd., 2020, s. 727).

Hastalık, 2-14 gün süren bir kuluçka süresini, yüksek ateş (39 derece), öksürük ve nefes darlığ1 gibi belirti ve semptomları içermektedir. Ağır hastalanan ve ölen kişilerin büyük kısmı 65 yaş ve üzeri ve altta yatan hastalıkları (akciğer hastalıklanı, organ yetmezlikleri, kanser, diyabet, bağışıklık baskılayan hastalıklar) olan kişilerden oluşmaktadır (https://www.ttb.org.tr). 
Başlangıçta Çin daha sonra tüm dünyadaki COVID-19 hastalarının sayısı hızla arttığından, SARSCoV-2'nin yayılmasını önlemek en önemli ve en acil görevdir (Nishuira vd., 2020, s. 1-3). Tüm ülke yönetimleri aldıkları ve alacakları tedbirlerle bu pandeminin yayılım hızını yavaşlatmalıdırlar. SARS-CoV2'nin insandan insana bulaşımının damlacıklar veya yakın temaslar yoluyla yayıldığı bilinmektedir ( $\mathrm{Li}$ vd., 2020: 448-454). Virüs bulaşmasını azaltmak için erken teşhis, sosyal mesafeye ve izolasyon önemlidir. Ayrıca, kalabalık yerlerde yakın izleme de önemlidir. SARS ve COVID-19'un olası patojenlerinin her ikisi de vahşi hayvanlardan elde edilir. Bu nedenle, vahşi hayvanları avlamak, satmak ve yemek ekosisteme ciddi zarar vermekle kalmamakta, aynı zamanda salgin hastalıkların yayılmasina da neden olmaktadir. $\mathrm{Bu}$ nedenle, tüm yaban hayatı ticaretinin yasaklanması, viral yaygınluğın önlenmesi için etkili bir önlemdir. Koruyucu giysi giymek, sağlık personelini solunum yolu virüslerinin enfeksiyonundan koruyabilmektedir. Yayınlanmış hiçbir makalede SARS-CoV'ye karşı henüz bir aşı tanımlanmamıştır (Xu vd., 2020, s. 6).

\section{Kriz, Özellikleri ve Aşamaları}

Kriz, en genel ifadeyle örgütlerin beklemedikleri bir anda aniden ortaya çıan ve genellikle örgütlerin hazırlıksız yakalandıkları bir durumdur. Kelime anlamı olarak kriz bir işin, bir olayın geçtiği karışık evre, içinden çıkılması zor, aniden ortaya çıan kötüye gidiş ve tehlikeli durum anlamına gelmektir (Can, 2005: 387). Literatürde bazı araştırmacılar krizi kurumun, toplumun ve ülkenin varlığını tehdit eden şartlara müdahale etmede yetersiz kalma, bazı araştırmacilar ise beklenmeyen şartların üstesinden gelme zorunluluğu ve ivediliği şeklinde ele almışlardır (Aksu, 2009, s. 2436).

Örgütlerin erken uyarı sistemlerinin farkına varılamayan veya varsa bile örgüt yönetimleri tarafından çok fazla dikkate alınmayan, iş yapma usul ve sistemlerini devre dışı bırakan, yöneticiler ve çalışanlar üzerinde paniğe yol açan ve örgütsel hedefleri olumsuz etkileyen gelişmelerdir (Bulduklu ve Karaçor, 2017, s. 280).

Krizler her ne kadar beklenilmeyen durumlar olsa da beklenilmeyen duruma hazırllklı yakalananlar ile hazırlıksız yakalananlar arasında doğal bir farkın ortaya çıkması kaçınılmazdır (Kadıbes,egil, 2003, s. 55). Krizler çok farklı nedenlerle ortaya çıkabilmekte ve bu bağlamda farklı şekillerde sınıflandırılabilmektedir. Türüne göre de krizlerin yol açtığı bireysel, toplumsal, örgütsel ve ülkesel etki ve sonuçları farklı olabilmektedir. Türü ve sonuçları ne olursa olsun krizler her zaman olumsuz çağrsşımlar yapmakta, küreselleşmeyle birlikte değişen ekonomik, teknolojik, toplumsal yap1 ve gelişmeler nedeniyle hem daha geniş alanlarda yıkıcı etkilere neden olmakta hem de örgütlerin ve toplumların krizlerle karşılaşma ihtimallerini artırmaktadır (Bulduklu ve Karaçor, 2017, s. 280).

Kriz, uygun şekilde ele alınmadığı takdirde olumsuz sonuçları olabilecek önemli bir tehdit olarak tanımlanmaktadır. Kriz yönetiminde tehdit, bir krizin bir kuruluşa, paydaşlarına ve bir sektöre verebileceği potansiyel zararları ifade etmektedir. Bir kriz üç farklı tehdit oluşturabilmektedir. Bunlar (1) kamu güvenliği, (2) finansal kayıp ve (3) itibar kaybı. Endüstriyel kazalar, salgın hastalıklar ve ürün hasarı gibi bazı krizler yaralanmalara ve hatta can kayıplarına neden olabilmektedir. Krizler operasyonları aksatarak, pazar pay1/satın alma niyetinde bir kayıp yaratarak veya krizle ilgili davaları ortaya çıkararak finansal kayıplara da yol açabilmektedir. Büyük küçük tüm krizler kuruluşların itibarını zedelemektedir. Aslında bu üç tehdit birbiriyle ilişkilidir (Coombs, 2007). Bu bağlamda krize etkili bir müdahale kuruma rekabetçi bir avantaj kazandırırken; etkisiz kriz tepkisi rekabetçi bir dezavantaja neden olmakta, hatta bir kurumun varlığını tehlikeye atabilmektedir (Garcia, 2006, s. 4).

\section{Kriz Yönetimi ve Salgın Durumlarında Kriz Yönetimi}

Kriz, mikro boyutta örgütlerin makro boyutta ülke ekonomilerinin ciddi anlamda maddi ve manevi kayıplar yaşamalarına neden olan olumsuzluklardır. İçinde bulunduğumuz küresel sosyal ve ekonomik koşullarda krizler kaçınılmaz olgulardır. Dolayısıyla önemli olan krizle karşılaşıldığında krizi ertelemenin veya geçiştirmenin değil, potansiyel olarak her zaman ortaya çıkma ihtimalinin bulunduğu bilinciyle krize hazırlıklı olmak suretiyle krize girmemeye ya da krizi en az hasarla atlatabilmenin ve krizden bir takım kazanımlar elde ederek çıkmanın yollarını bulmaktır (Narbay, 2005, s. 51).

Örgütlerin ve toplumların beşerî, finansal, ruhsal ve birçok açıdan zarar görmesi anlamına gelen krizler yöneticilerin sağlıklı karar verme kapasitelerini bozarak olumsuzluğun derinleşmesine yol açmaktadır. Bu nedenle krizlerden en az zararla kurtulabilmek için örgüt ve ülkelerin stratejik bir öngörüyle yönetilmeleri gerekmektedir (Bulduklu ve Karaçor, 2017, s. 283-284). 
Örgütler ve toplumsal yapılar normal işlevlerini yerine getirmeye çalışırken istenmeyen, öngörülemeyen ve ç̋̈zümü aciliyet gerektiren bir durumla karşlaştıklarında kriz söz konusu olmaktadır (Akdağ ve Arklan, 2013, s. 38). Kriz yönetimi ürünler, hizmetler, üretim süreçleri, şirket itibarı, çalışanlar, çevre ve topluluklara yönelik tehditlerin risk değerlendirmesini ve kriz plan ve süreçlerinin tespiti, önlenmesi için tasarlanması ve uygulanmasını içermektedir (Mitroff, 1994, s. 102; Pollard ve Hotho, 2006, s. 722-730). Örgütlerin normal dönemlerdeki is, yapma prosedürleri ve karar verme uygulamalarıyla kriz şartlarını yönetebilmeleri mümkün değildir. Bu nedenle kriz şartlarına uygun yönetim politikalarının geliştirilmesi ve uygulanması gerekmektedir (Can, 2005, s. 397). Krize hazırllklı olmak ve bir kriz anında nasıl davranılması gerektiğini bilmek kriz yönetiminin özünü oluşturmaktadır. Kriz sonrası normalleşme döneminde durumun tekrarlamaması için gerekli tedbirler alınmalı ve erken uyarı sistemleri geliştirilmelidir (Aksu ve Deveci, 2009, s. 449).

Kriz yönetiminin başarısı kriz sinyallerinin zamanında alınabilmesine ve gerekli tedbirlerin yürürlüğe konulabilmesine bağlı bulunmaktadır (Can, 2002, s. 333). Bu bağlamda kriz yönetim ekibinin krizi algilama biçim ve becerileri ile etkin karar verebilme kapasiteleri son derece önemlidir. Krize hazırlıklı yakalanabilmek ve krizden korunabilmek için yöneticilerin dış çevreyi yakından takip ve analiz etmeleri, dünyada meydana gelen gelişmeleri gözlemlemeleri gerekmektedir (Aksu ve Deveci, 2009, s. 449; Demirtaş, 2000, s. 354-359). Ülke ve örgüt yöneticilerinin, kriz ekiplerinin ve onların danışmanlarının krizi erken algılayabilme ve zamanında tepki verebilme yetenekleri başarı edebilmek açısından önem arz etmektedir. Etkili kriz yönetimi esnek, yaratıcı düşünmeyi, objektif ve cesur kararlar almayı gerektirmenin yanı sıra birbirini tamamlayan özelliklere sahip bireylerden oluşan takım çalışmasına daha fazla ihtiyaç, duymaktadır (Haşit, 2000, s. 66-67). Yöneticilerin yönetsel yetenek ve becerileri, her s,eyin yolunda gittiğ zamanlarda değil daha çok risk ve kriz ortamlarında ehemmiyet kazanmaktadır (Maya, 2014, s. 211).

Kriz yönetimi, bir şirketin ana ürünleri, hizmetleri, üretim süreçleri, çalışanları, çevresi ve toplulukları için büyük bir tehdit oluşturabilecek bir dizi kriz ve kuvvetin devam eden, birbiriyle ilişkili değerlendirmeleri veya denetimleridir. Kriz yönetimi ayrıca kriz tespiti, önleme, hazırlık, içerme, kurtarma ve öğrenme için kilit planların, prosedürlerin ve mekanizmaların tasarımı, yeniden tasarımı ve uygulanması için bir dizi faaliyetten oluşmaktadır (Mitroff, 1994, s. 102).

Kriz yönetimi, örgütün ve toplumsal yapının sahip olduğu tüm maddi ve gayri maddi varlıklar, imaj ve itibarın zarar görmemesi için yürütülen sistemli ve planlı çabaların bütünüdür. Proaktif bir şekilde planlanıp reaktif olarak yürütülmeyi gerektiren kriz yönetiminin en can alıcı kısmını paydaşlarla olan iletişimin doğru bir şekilde yönetilebilmesi oluşturmaktadır. Tüm paydaş ve kamuoyu ile iletişimin karşılıklı güveni tesis edecek, sağlıklı bilgilendirmeyi gerçekleştirecek ve etkileşime firsat verecek şekilde halkla ilişkiler stratejileri kapsamında yönetilmesi krizin başarılı olarak atlatabilmesinin ön koşuludur (Bulduklu ve Karaçor, 2017, s. 284).

Başarılı bir kriz yönetiminin ön koşulu olan iletişimin sağlıklı ve doğru bir şekilde yönetilebilmesinin etkin bir liderliğe gereksinim duyduğu bilinen bir gerçektir. Yönetim özü itibariyle karar verme ile ilgili olduğundan risk taşıyan bir çaba ve girişimdir. Bu süreçte yöneticiler, örgütteki riskleri etkili bir şekilde yöneterek krizleri önleyebilmeli ya da krizin yol açtı̆̆ maliyetleri azaltabilmelidir (Hittle ve Leonard, 2011, s. 1190-1191).

Politika yapıcılar için en önemli ve en az anlaşılan rol, acil durum iletişiminin diğer acil durum müdahale ekipleri ve halk tarafindan güvenilebileceğinden emin olmaktır. $\mathrm{Bu}$, en azından, güven oluşturmaya yardımcı olan ve sürpriz zamanlarda iletişim planlarını zorunlu kılan sürekli iletişim sağladıkları anlamına gelmektedir (Longstaff ve Yang, 2008, s. 3). Bu bağlamda kriz durumunda örgütü ve toplumu içine düştüğü panik ortamından kısa sürede çıkaracak, hızlı ve doğru kararları alıp uygulayabilecek, sağduyuyu esas alacak, popülist değil reel politikalar belirleyebilecek bir yönetim ve liderliğe ihtiyaç duyulmaktadır. Kriz yönetimi ve liderliği doğru zamanlamayı içeren eylem planlarını gerektirmektedir (Bulduklu ve Karaçor, 2017, s. 284). Kriz kavramı anında müdahale etmeyi gerektiren bir durum olarak algilanmaktadır. Korkmazyürek ve Basım (2008, s. 1-2) kriz ile acil durum arasındaki fark1 gelecekte yol açabilecekleri tehlike açısından ayrıştırmaktadır. Bu bağlamda krizi önlenememesi durumunda örgütün varlığını tehlikeye sokabilen bir olgu olarak ele almışlarken, acil durumu, potansiyel tehlikeleri açısından gelecekte var olmayı riske atma tehlikesi bulunmayan bir durum olarak ele almaktadırlar.

Van der Heyden ve Nathanial (2020) geçmişte bugün yaşadığımız koronavirüs salgını büyüklüğünde yaşanılmış krizlerin sayısının son derece az olduğunu ileri sürerek, liderlerin bu kriz karşısında bocaladıklarını belirtmektedirler. Geçmişi nesnel ve rasyonel bir tavırla araştırmak liderlere 
karşılaşabilecekleri tehditler hakkında genel ve doğru bir fikir vermelidir. Potansiyel bir tehlike ortaya çıktı̆ı̀nda, deneyimli kriz yöneticilerinin kullanabilecekleri temel ilkeler bulunmaktadır. Örneğin finans dünyasında yıllarca süren krizlerle mücadelelerde öğrenilen ve tecrübe edilen ilkelerin çoğu koronavirüs salgını ile mücadele etmede ve bu krizi yönetmede kolayca uygulanabilmektedir. Bu ilkeler, çeşitli düzeyde yaşanılan global krizler için geçerli beş aşamalı bir çerçeve içinde düzenlenebilmektedir. Söz konusu yazarlar koronavirüs krizinde de kullanılabilecek kriz yönetimindeki beş aşamayı " $5 E$ " ile kategorize etmektedirler (Van der Heyden ve Nathanial, 2020):

1. Aşama-Engage: Krizi çerçevelemeye katılın ve çerçevelemeyi doğru yapın: Asya ülkelerinin koronavirüs ile mücadeledeki göreceli başarılarının temelinde kriz yöneticilerinin anlamlı bir tepki gösterebilme adına sorunu ve krizi çerçevelemeleri gelmektedir. Krizlerin nasıl ortaya çıktı̆ı ve insanların bunlara nasıl tepki verdikleri ile ilgili kalıpları belirlemek deneyim gerektirmektedir. İtalya ve Fransa gibi Avrupa ülkeleri için uygun çerçeveleme, sağllk sisteminin çökmesini önlemek için "eğriyi düzleştirmeyi”" vurgulayacaktır. Bir diğeri, en savunmasız olanları derhal korumak ve önceliklendirmektir. Bir kez tasarlandığında, çerçeveleme iş birliğine ihtiyaç duyan veya etkilenecek olan herkese iletilmelidir. Ne yazık ki, birçok Batılı ülkenin liderleri krizin başlangıç aşamalarında sağlıklı bir çerçeveleme yapamayarak krizin derinleşmesine ve kriz yönetim sistemlerinin felç olmalarına sebebiyet vermişlerdir. Örneğin, COVID-19 enfeksiyonları için Başkan Trump, yeni koronavirüsün mevsimsel gripten daha az öldürücü olduğunu ima eden yaniltıcı tweetler yayınlamıştır.

2. Aşama-Explore: Krizi ve onunla nasıl mücadele edeceğinizi keşfedin: Krizle mücadele etmeye başlarken öncelikler, hedefler ve planlama açıça bildirilmelidir. Gerçekçilik ve umut, belirsizliğe uyum sağlama ve şeffaflı̆ga bağllık arasında hassas bir denge kurulmalıdır. En acil ve ulaşılabilir hedeflere odaklanarak, bilgi paylaşımını sağlıklı bir şekilde sürdürmek kriz yönetim sürecindeki belirsizliği ortadan kaldırmakta ve doğrudan karar verme sürecine girmeyenleri güçlendirmektedir. Örneğin, Singapur ve Türkiye Cumhuriyeti hükümeti, her yeni COVID-19 vakası hakkında - yaş, seyahat geçmişi ve ilgili hastalık kümeleri de dahil olmak üzere - halka açık anonimleştirilmiş bilgileri vermekte, böylece vatandaşlar hükümet yetkililerinin kullandığı bilgilere erişebilmektedir.

3. Aşama-Explain: Neye karar verdiğinizi, neden ve nasıl çalışacağınızı açıklayın, sonra harekete geçin: Bir krizde, eylemsizlik her zaman sorunu daha da kötüleştirmektedir. Başarısız bir eylem dahi ilerlemeye yol açan bir şey öğretebilir. Ancak, alt yapısı önceden hazırlanılmadığı sürece başarısızlık panik, kaos ve güvenilirlik kaybına yol açabilmektedir. Kriz yöneticileri, en az üç savunma hattı, askeri, bankacilık ve diğer bağlamlarda da benimsenen bir strateji ile savaşa girmelidir. ABD ve Avrupa merkez bankaları, koronavirüs korkularının neden olduğu ekonomik gerilemeyi sağlamlaştırmak için erken tedbirler uygulamaya koyduklarında finansal piyasalar için uygun bir şekilde iletişim kurulamaması olumsuzluklara yol açmıştır. Tam bir açıklama yapılmaksızın, önlemler pazara tedaviden ziyade ekonomik panik belirtisi olarak yansımış ve büyük çaplı satışları tetiklemiştir. Eğer bu ilk önlemler ekonomiyi desteklemek için çok daha büyük bir teklifin ilk adımı olarak halka aktarılmış olsaydı, amaçlanan amacını yerine getirmiş olabilirlerdi.

4. Aşama-Execute: Odaklanma ve sürekli izleme ile yürüt: Doğru metriğe, sonuçları doğru bir şekilde yansıtan ve liderliğe güven üreten bir stratejiye güvenilmediğinde belirlenen stratejilerin işe yarayıp yaramadığını bilmek zorlaşmaktadır. Örneğin COVID-19 ile mücadelede sadece vaka ve ölüm sayılarına odaklanmak yanıltıcı ve umutsuzluğa neden olabilmektedir. Çünkü virüse yenik düşenlerin orantısız bir sayısı yaşlılardan oluşmaktadır. Yaş grubuna göre ölüm oranları, benzer nitelikteki geçmiş salgınlara kıyasla, daha kesin bir tablo çizecektir.

5. Aşama-Evaluate: Yeni bilgiler ve geri bildirimler geldikçe liderliğinizin yanı sıra çabalarınızı değerlendirin, öğrenin ve uyarlayın: İyi zamanlarda değerli bir liderlik niteliği olan alçakgönüllülük, bir kriz sırasında zorunlu hale gelebilmektedir. Kaçınılmaz olarak, hatalar yapılacaktır. Kriz, bir liderin gerçek karakterini vurgular çünkü halka uzun süre ikna edici davranmak çok zordur. Açıkçası sorumluluğu kabul etmek, rotayı değiştirmek için proaktif bir isteklilik göstermek ve yeni yönlerle başkalarına açıkça danışmak, hataların kolektif çabayı ölümcül olarak baltalamasını önleyecektir.

Covid-19 gibi bulaşıcı hastalıklar ve salgınlar, afetler, büyük çaplı kazalar, başarısız tıbbi uygulamalar ve sağllk sisteminin işleyişi ile ilgili sorunlar tüm ülkelerde görülebilen ve sağllk sektöründe krize yol açan kriz türlerindedir (Panos vd., 2009, s. 106). Bu tür salgin krizlerinin yönetiminde kriz yönetiminin bilgiyi 
paylaşma, açık iletişim kurma ve halka karantina düzenlerini kabul ettirme becerileri hayati önem arz etmektedir (Quah ve Hin-Peng, 2004, s. 365).

Mahase (2020) Dünya Sağlık Örgütü (DSÖ-WHO) verilerine göre virüsün yayıldığg 2020'nin ilk aylarında maske, eldiven gibi kişisel koruyucu ekipman ve solunum cihazlarına olan talebin kriz öncesi döneme göre 100 kat ve söz konusu malzeme fiyatlarının da yaklaşık 20 kat arttı̆̆ını ileri sürmektedir (Mahase, 2020'den Akt: Acar, 2020, s. 9)

Dünya Sağlık Örgütu’nün yayınladığ1 raporlarda belirlenen tavsiyeler doğrultusunda ülke yönetimleri tarafindan eğitim, seyahat, sağlık, ekonomi, ticaret, ulaşım, spor gibi birçok alanda çeşitli önlemler uygulanmıştır (Acar, 2020, s. 14-15). Koronavirüsle mücadelede sadece hükümetler, merkez bankalar1 ve Dünya Sağlık Örgütü değil özel sektör de kilit bir rol oynamalıdır. Şirketler COVID-19'a yanıt verirken, ahlaki ifadeleri pratik eylemlerle destekleyen iş liderleri ön plana çıkacaklardır. Küresel bir krizle mücadeleye yardımcı olurken, çalışanların korunması ve toplumun acil ihtiyaçlarını karşılamak için benzersiz yeteneklerinin yeniden konuşlandırılması daha sadık işgücü ve kamu yararı oluşturabilmektedir. COVID-19 krizi tüm boyutları ile gözlerimizin önünde gelişmektedir. Siyasi liderler, finansal kurumlar ve küresel yönetişim yapıları ciddi şekilde test edilmektedir (www.weforum.org).

\section{Araştırmanın Metodolojisi}

\section{Çalışmanın Amacı}

Bu çalısmanın yapılmasının amacı bütün dünyaya yayılarak 11 Mart 2020 tarihi itibariyle Dünya Sağlık Örgütü tarafindan pandemi yani küresel salgin olarak ilan edilen Yeni Tip Koronavirüs (Covid-19) hastalı̆g döneminde başlica gelişmiş ülkelerin ve gelişmekte olan ülkelerin kriz yönetim becerilerinin değerlendirilmesidir. Bu amaç doğrultusunda ülkelerin krizin başlangıcından itibaren ilk 14 günlük süredeki krize yönelik hareketlerinin incelenerek IMF ekonomik sınıflandırmasına göre kıyaslanması da araştırma amaçları arasında yer almaktadır. Her ülke için kriz başlangıcı süresi ülkede açıklanan ilk resmi vakanın ardından geçen 14 günlük süreç olarak ele alınmışır. Bunun temel sebebi her ülkede farklı tarihlerde ilk hastalık tespitinin yapılmasıdır. Her ülke kendi ilk resmi vakasından sonraki ilk 14 günlük süreç için değerlendirilmiştir. Vaka ya da ölüm sayıları, yayılma oranları vb. bilgi ve bunlara dair çeşitli istatistikler bu çalışmanın araştırma kapsamı içinde yer almamaktadır. Araştırılan konu net olarak; ülkelerin kriz durumunda yerine getirmeleri gerekebilecek kriterleri belirli bir süre içinde gerçekleştirip gerçekleştirmediğini belirlemektir.

\section{Çalışmanın Kapsamı}

IMF (International Money Fund) ülkeleri çeşitli kriterlere göre ekonomik durumları açısından sınıflandırmaktadır. Bu çalısmanın kapsamını IMF'nin yaptığı sınıflandırmalardan iki tanesi oluşturmaktadır. Başlıca Gelişmiş Ülkeler; İtalya, Fransa, Kanada, A.B.D., Birleşik Krallık, Japonya ve Almanya'dan oluşmaktadır. Gelişmekte olan ülkelerin sayısı yüzden fazla olmasına rağmen bu ülkelerden de yedi ülke bu çalısma için seçilmiştir. Daha rahat kıyaslama yapabilmek için her iki gruptan da eşit sayıda ülke araştırma kapsamına dahil edilmiştir. Gelişmekte olan ülkeler arasından yedi ülke belirlenirken İnsani Gelişme Endeksi (Human Development Index) göz önünde bulundurulmuştur. İnsani Gelişme Endeksi (IGE) 1993 yllından bu yana Birleşmiş Milletler tarafindan tanınan ve Ul Haq (1989) tarafindan geliştirilmiş olan bir göstergedir. İGE bir ülkenin gelişmişlik düzeyiyle ve ekonominin yaşam niteliğini ne düzeyde etkilediği ile ilgilenmektedir (Ul Haq, 1989; https://www.un.org, 2020). Araştırma kapsamında İGE puanları "çok yüksek" olan ülkeler seçilmeye özen gösterilmiştir. İGE'ye göre dünya ortalaması $(0,731)$ üzerinde olması ülke seçiminde bir başka kriteri oluşturmaktadır. Araştırma kapsamında incelenecek tüm ülkelerin İGE puanları "yüksek" veya "çok yüksek" olarak tespit edilmiştir. Tablo 2'de Araştırma kapsamındaki ülkelerin IMF ekonomik sınıfları ve de İGE puanları verilmiştir. 
Tablo 2. IMF Ekonomik Sinflarn ve IGGE Verileri

\begin{tabular}{|c|c|c|c|}
\hline Ülke & IMF Ekonomik Sinıfi & İnsani Gelişme Endeksi Puanı & İnsani Gelişme Endeksi Sınıfi* \\
\hline İtalya & & 0,883 & Çok Yüksek \\
\hline A.B.D. & & 0,920 & Çok Yüksek \\
\hline Birleşik Krallık & & 0,920 & Çok Yüksek \\
\hline Japonya & Başlıca Gelişmiş Ülkeler & 0,915 & Çok Yüksek \\
\hline Kanada & & 0,922 & Çok Yüksek \\
\hline Fransa & & 0,891 & Çok Yüksek \\
\hline Almanya & & 0,939 & Çok Yüksek \\
\hline Polonya & & 0,872 & Çok Yüksek \\
\hline Türkiye & & 0,806 & Çok Yüksek \\
\hline İran & & 0,797 & Yüksek \\
\hline Arjantin & Gelişmekte Olan Ülkeler & 0,830 & Çok Yüksek \\
\hline Brezilya & & 0,761 & Yüksek \\
\hline Rusya & & 0,824 & Çok Yüksek \\
\hline Malezya & & 0,804 & Çok Yüksek \\
\hline
\end{tabular}

( ${ }^{*}$ çok yüksek $\geq 0,800$; yüksek $\geq 0,700$ )

Kaynak: http://hdr.undp.org/

\section{Kisıtlilıklar ve Varsayımlar}

İncelenen tüm ülkelerin açıkladığı bilgilerin doğruluğu kabul edilmiş ve araştırma bu temelde gerçekleştirilmiştir. Açıklanan tüm bilgilerin doğru olduğu burada bir varsayım oluşturmaktadır. Daha net bir ifadeyle; açıklanan ilk resmi vaka o ülkedeki ilk vaka olmayabilir ancak tespit edilen ilk vaka olduğu için bu durum ilk resmi vakanın gerçekten ilk vaka olduğu varsayımını gerektirir. Bilgiye ulaşımda yalnızca resmi açıklamalar ve resmi kanallardan bilgi sağlanabilmesi de veri toplama konusunda tekel oluşturduğu için bu çalışma için bir kısıtlllık unsurudur.

\section{Veri Toplama Aracı}

Çalışma kapsamında veri toplayabilmek amacıyla Tablo 3'te ayrıntılı bir şekilde gösterilen "Pandemide Kriz Yönetimi Kriterleri” oluşturulmuştur. Kriterler oluşturulurken literatürdeki kriz yönetimine dair çalısmalar ayrıntılı bir şekilde incelenmiştir. İlk 5 kriter belirlenirken Aksu ve Deveci (2009) tarafindan geliştirilen 3 boyut ve 31 ifadeden oluşan "İlköğretim Okul Müdürlerinin Kriz Yönetim Becerileri Ölçeği”"nin 8 ifadeden oluşan kriz dönemi boyutundaki ifadelerden yararlanılmışıtır. Bahsedilen ölçekteki ifadeler incelenmek istenen konuya göre revize edilerek geliştirilmiş ve bazı ifadeler birleştirilmiş, bazı ifadeler ise konu bütünlüğünden uzaklaşmamak adına çıkartılmıştır. Dünya Sağlık Örgütünün tavsiyelerine göre ülkeler arası giriş çıkışın yavaşlatılması ya da uluslararası uçuşların durdurulması bahsedilen salgının yayılma derecesinde oldukça etkili olduğundan dolayı ülke giriş çıkışlarındaki salgınlara yönelik önlem ve kısıtlamalar bu araştırmanın 6. kriterini oluşturmaktadır. Benzer şekilde Acar (2020, s. 16) çalışmasında alınması gereken önlemleri sıralamış ve sınır güvenliği ve uluslararası dolaşımdan bahsetmiştir. Aynı çalısmadaki önlemler arasında toplumsal tedbirlerin alınması ve eğitime ara verilmesi gibi engelleyici önlemlerin de yer alması bu çalışmanın 7. kriterinin belirlenmesinde rol oynamaktadır.

Quah ve Hin-Peng (2004, s. 365) salgnn krizlerinin yönetiminde karantina gibi önlemlerin önemini vurgulamıştır. Ancak toplumsal farklılıklardan dolayı bu durum kültürel bir değerin aşağılanması olarak algılanabileceğinden dolayı (Japonya'da karantina uygulaması devlet yönetimi tarafından Japon halkına yapılan bir aşağılama şeklinde görülebileceğinden ve böyle bir hakkın kimsede olmadığından dolayı karantina kararı almak yerine halkı sosyal izolasyona davet etmekle yetinmiştir) karantina ve sosyal izolasyon çağrısı farklı kriterler olarak ele alınmışır. Bu bağlamda 8. ve 9. kriterler oluşturulmuştur. Van der Heyden ve Nathanial (2020) yukarıda ayrıntılı şekilde de belirtildiği üzere kriz döneminde oluşan ya da oluşabilecek ekonomik panik ve dünya borsalarının tamamında yaşanan değer kaybının erken alınmayan ekonomik önlemlerden kaynaklandığını belirtmektedir. Bu görüşe istinaden kişi ve kurumlara yönelik ekonomik desteklerin erken sağlanması bu çalışmanın 10. kriterini oluşturmaktadır. Belirlenen tüm kriterlerin ilk 14 gün (Zhu vd., 2020, s. 727; T.C. Sağlık Bakanllğ1 Covid-19 Rehberi, 2020, s. 5; WHO, Coronavirus Disease (COVID-19) Outbrake, 2020) içerisinde gerçekleştirilmesi özellikle salgının yayılmasında önemli bir süre olarak ele alındığı için belirlenmiştir.

"Pandemide Kriz Yönetimi Kriterleri” bu çalısma için evet ve hayır şeklinde yanıtlanmaktadır. Bu çalısma kapsamında 14 günlük süre kritik olduğu için bu şekilde belirlenmiştir. Ancak farklı durum ve 
süreler incelenecek olursa Likert tipi derecelendirmeye yönelik şekilde de kullanılabileceği düşünülmektedir.

Tablo 3. Pandemide Kriそ, Yönetimi Kriterleri

\begin{tabular}{|c|c|c|c|}
\hline No & Kriter & \multicolumn{2}{|c|}{ Yanitlar (Puanlar) } \\
\hline 1 & Krizden korunmak amacıyla kriz yönetim ve iletişim planı hazırlanmıştır & Evet (10 puan) & Hayır (0 puan) \\
\hline 2 & Kriz döneminde uygulanacak acil eylem planı veya alternatif planlar hazırlanmıştır & Evet (10 puan) & Hayır (0 puan) \\
\hline 3 & Kriz kontrol ve risk denetim takımları kurulmuştur & Evet $(10 \mathrm{p}$ & $\mathrm{Hal}$ \\
\hline 4 & Tüm ilgili çalışanlar kriz yönetim planından haberdar edilmiştir & Evet $(10$ & \\
\hline 5 & $\begin{array}{l}\text { Tüm vatandaşlara yaşanılan kriz hakkında kesinleşmiş bilgiler sürekli şekilde } \\
\text { verilmiştir }\end{array}$ & Evet (10 puan) & Hayır (0 puan) \\
\hline 6 & $\begin{array}{l}\text { Ülke giriş çıkışlarında salgına yönelik kısıtlamalar getirilmiş ve gerekli önlemler } \\
\text { alınmıştır }\end{array}$ & Evet (10 puan) & Hayır (0 puan) \\
\hline 7 & $\begin{array}{l}\text { Kriz yöneticileri tarafindan toplumsal tedbirler alınmıştır (İnsanların toplu şekilde } \\
\text { bir araya gelmemelerini sağlamak amaciyla okulların kapatılması, konser ve spor } \\
\text { müsabakalarının ertelenmesi ya da yasaklanması gibi) }\end{array}$ & Ev & $\mathrm{Ha}$ \\
\hline 8 & $\begin{array}{l}\text { Kriz yöneticileri tarafindan sosyal izolasyona yönelik tavsiye, destek ve teşvikler } \\
\text { sağlanmıştır }\end{array}$ & Evet (10 puan) & Hayır (0 puan) \\
\hline 9 & $\begin{array}{l}\text { Belirli bir grup veya tüm toplum için kısmi ya da tam zamanlı sokağa çıkma yasağı / } \\
\text { kısıtlaması ya da getirilmiştir. }\end{array}$ & Evet (10 puan) & Hay \\
\hline 10 & Krizden etkilenen kişi/kurumlar için destekleyici sosyal yardım planı yapılmıștır & Evet (10 puan) & Hayır (0 puan) \\
\hline
\end{tabular}

\section{Değerlendirme}

Tablo 4'te kriterlerin gerçekleșme tarihleri yer almaktadır. Kalın karakterle yazılan tarihler, kriterin ilk 14 günlük süre içinde gerçekleştiğini ifade etmektedir. (-) ifadesi ilgili kriterin bu çalışmanın hazırlandığ1 tarih itibariyle halen gerçekleşmemiş olduğunu ifade etmektedir. Beşinci kriterde tarih değil (+) ve (-) ifadeleri kullanılmıştır. Bunun sebebi "Tüm vatandaşlara yaşanılan kriz hakkında kesinleşmiş bilgiler sürekli şekilde verilmiştir" ifadesinin ilk 14 gün boyunca sürekli olarak gerçekleşip gerçekleşmediğinin tarih belirterek ifade edilemeyecek olmasıdır. 7, 8, 9 ve 10. kriterlerde ifade edilenlerden herhangi birinin ilk gerçekleşme tarihi baz alınmıştır. Tüm ifadelere dair bilgiler ülkelerin resmi internet siteleri, sağılk bakanlı̆ğ veya pandemi ile ilgili resmi internet siteleri ve Dünya Sağlık Örgütü'nün resmi internet sitesinden edinilmiștir.

Tablo 4. Ülkelerin Kriterleri Gerçeklestirme Taribleri

\begin{tabular}{|c|c|c|c|c|c|c|c|c|c|c|c|c|}
\hline & \multirow{2}{*}{$\begin{array}{c}\text { İlk resmi } \\
\text { vaka } \\
\text { açıklanma } \\
\text { tarihi }\end{array}$} & \multirow{2}{*}{$\begin{array}{c}\text { İlk } 14 \\
\text { günlük } \\
\text { süre } \\
\text { sonu }\end{array}$} & \multicolumn{10}{|c|}{ Kriterlerin gerçekleştirilme tarihi } \\
\hline & & & 1 & 2 & 3 & 4 & 5 & 6 & 7 & 8 & 9 & 10 \\
\hline İtalya & 31.01 .2020 & $\begin{array}{c}14.02 . \\
2020\end{array}$ & $\begin{array}{c}31.01 . \\
2020\end{array}$ & $\begin{array}{c}31.01 . \\
2020\end{array}$ & $\begin{array}{c}31.01 . \\
2020\end{array}$ & $\begin{array}{c}31.01 . \\
2020\end{array}$ & + & $\begin{array}{c}31.01 . \\
2020\end{array}$ & $\begin{array}{c}23.02 . \\
2020\end{array}$ & $\begin{array}{c}08.03 . \\
2020\end{array}$ & $\begin{array}{c}08.03 . \\
2020\end{array}$ & $\begin{array}{c}05.03 . \\
2020\end{array}$ \\
\hline A.B.D. & 23.01.2020 & $\begin{array}{c}06.02 . \\
2020\end{array}$ & $\begin{array}{c}29.01 . \\
2020\end{array}$ & $\begin{array}{c}29.01 . \\
2020\end{array}$ & $\begin{array}{c}29.01 . \\
2020\end{array}$ & $\begin{array}{c}25.02 . \\
2020\end{array}$ & + & $\begin{array}{c}31.01 . \\
2020\end{array}$ & $\begin{array}{c}21.03 . \\
2020\end{array}$ & $\begin{array}{c}16.03 . \\
2020\end{array}$ & $\begin{array}{c}21.03 . \\
2020\end{array}$ & $\begin{array}{c}18.03 . \\
2020\end{array}$ \\
\hline $\begin{array}{l}\text { Birleşik } \\
\text { Krallik }\end{array}$ & 31.01 .2020 & $\begin{array}{c}14.02 . \\
2020 \\
\end{array}$ & $\begin{array}{c}10.02 . \\
2020 \\
\end{array}$ & $\begin{array}{c}10.02 . \\
2020 \\
\end{array}$ & $\begin{array}{c}10.02 . \\
2020 \\
\end{array}$ & $\begin{array}{c}10.02 . \\
2020 \\
\end{array}$ & + & $\begin{array}{c}22.01 . \\
2020\end{array}$ & $\begin{array}{c}12.03 . \\
2020 \\
\end{array}$ & $\begin{array}{c}02.03 . \\
2020 \\
\end{array}$ & $\begin{array}{c}23.03 . \\
2020 \\
\end{array}$ & $\begin{array}{c}12.03 . \\
2020 \\
\end{array}$ \\
\hline Japonya & 16.01.2020 & $\begin{array}{c}30.01 \\
2020\end{array}$ & $\begin{array}{c}30.01 . \\
2020\end{array}$ & $\begin{array}{c}30.01 . \\
2020\end{array}$ & $\begin{array}{c}30.01 . \\
2020\end{array}$ & $\begin{array}{c}30.01 . \\
2020\end{array}$ & + & $\begin{array}{c}01.02 . \\
2020\end{array}$ & $\begin{array}{c}25.02 . \\
2020\end{array}$ & $\begin{array}{c}28.02 . \\
2020\end{array}$ & - & $\begin{array}{c}27.02 . \\
2020\end{array}$ \\
\hline Kanada & 27.01 .2020 & $\begin{array}{c}10.02 . \\
2020 \\
\end{array}$ & $\begin{array}{c}06.03 . \\
2020 \\
\end{array}$ & $\begin{array}{c}06.03 . \\
2020 \\
\end{array}$ & $\begin{array}{c}06.03 . \\
2020 \\
\end{array}$ & $\begin{array}{c}06.03 . \\
2020 \\
\end{array}$ & + & $\begin{array}{c}16.03 . \\
2020 \\
\end{array}$ & $\begin{array}{c}12.03 . \\
2020 \\
\end{array}$ & $\begin{array}{c}06.03 . \\
2020 \\
\end{array}$ & $\begin{array}{c}25.03 . \\
2020 \\
\end{array}$ & $\begin{array}{c}11.03 . \\
2020 \\
\end{array}$ \\
\hline Fransa & 24.01 .2020 & $\begin{array}{c}07.02 . \\
2020 \\
\end{array}$ & $\begin{array}{c}13.03 . \\
2020 \\
\end{array}$ & $\begin{array}{c}13.03 . \\
2020 \\
\end{array}$ & $\begin{array}{c}13.03 . \\
2020 \\
\end{array}$ & $\begin{array}{c}13.03 . \\
2020 \\
\end{array}$ & + & $\begin{array}{c}17.03 . \\
2020 \\
\end{array}$ & $\begin{array}{c}01.03 . \\
2020 \\
\end{array}$ & $\begin{array}{c}01.03 . \\
2020 \\
\end{array}$ & $\begin{array}{c}16.03 . \\
2020 \\
\end{array}$ & $\begin{array}{c}31.03 . \\
2020 \\
\end{array}$ \\
\hline Almanya & 27.01 .2020 & $\begin{array}{c}10.02 . \\
2020\end{array}$ & $\begin{array}{c}02.03 . \\
2020\end{array}$ & $\begin{array}{c}02.03 . \\
2020\end{array}$ & $\begin{array}{c}02.03 . \\
2020\end{array}$ & $\begin{array}{c}02.03 . \\
2020\end{array}$ & + & $\begin{array}{c}28.01 . \\
2020\end{array}$ & $\begin{array}{c}24.02 . \\
2020\end{array}$ & $\begin{array}{c}11.03 . \\
2020\end{array}$ & $\begin{array}{c}16.03 \\
2020\end{array}$ & $\begin{array}{c}23.03 . \\
2020\end{array}$ \\
\hline Polonya & 04.03 .2020 & $\begin{array}{c}18.03 . \\
2020 \\
\end{array}$ & $\begin{array}{c}04.03 . \\
2020 \\
\end{array}$ & $\begin{array}{c}04.03 . \\
2020 \\
\end{array}$ & $\begin{array}{c}04.03 . \\
2020 \\
\end{array}$ & $\begin{array}{c}04.03 . \\
2020 \\
\end{array}$ & + & $\begin{array}{c}15.03 . \\
2020 \\
\end{array}$ & $\begin{array}{c}10.03 \\
2020 \\
\end{array}$ & $\begin{array}{c}31.03 . \\
2020\end{array}$ & $\begin{array}{c}24.03 . \\
2020\end{array}$ & $\begin{array}{c}18.03 . \\
2020\end{array}$ \\
\hline Türkiye & 11.03.2020 & $\begin{array}{c}25.03 . \\
2020 \\
\end{array}$ & $\begin{array}{c}12.03 . \\
2020 \\
\end{array}$ & $\begin{array}{c}12.03 . \\
2020 \\
\end{array}$ & $\begin{array}{c}12.03 . \\
2020 \\
\end{array}$ & $\begin{array}{c}12.03 . \\
2020 \\
\end{array}$ & + & $\begin{array}{c}24.01 . \\
2020 \\
\end{array}$ & $\begin{array}{c}16.03 . \\
2020 \\
\end{array}$ & $\begin{array}{c}15.03 . \\
2020 \\
\end{array}$ & $\begin{array}{c}21.03 . \\
2020 \\
\end{array}$ & $\begin{array}{c}18.03 . \\
2020 \\
\end{array}$ \\
\hline İran & 19.02.2020 & $\begin{array}{c}04.03 . \\
2020 \\
\end{array}$ & $\begin{array}{c}02.03 . \\
2020 \\
\end{array}$ & $\begin{array}{c}02.03 . \\
2020 \\
\end{array}$ & $\begin{array}{c}02.03 . \\
2020 \\
\end{array}$ & $\begin{array}{c}02.03 . \\
2020 \\
\end{array}$ & + & $\begin{array}{c}23.02 . \\
2020 \\
\end{array}$ & $\begin{array}{c}22.02 . \\
2020 \\
\end{array}$ & $\begin{array}{c}17.03 . \\
2020 \\
\end{array}$ & $\begin{array}{c}09.03 . \\
2020 \\
\end{array}$ & $\begin{array}{c}17.03 . \\
2020 \\
\end{array}$ \\
\hline Arjantin & 03.03 .2020 & $\begin{array}{c}17.03 . \\
2020 \\
\end{array}$ & $\begin{array}{c}28.01 . \\
2020 \\
\end{array}$ & $\begin{array}{c}28.01 . \\
2020 \\
\end{array}$ & $\begin{array}{c}28.01 . \\
2020 \\
\end{array}$ & $\begin{array}{c}28.01 . \\
2020 \\
\end{array}$ & + & $\begin{array}{c}25.02 . \\
2020 \\
\end{array}$ & $\begin{array}{c}15.03 . \\
2020 \\
\end{array}$ & $\begin{array}{c}11.03 . \\
2020 \\
\end{array}$ & $\begin{array}{c}20.03 . \\
2020 \\
\end{array}$ & - \\
\hline Brezilya & 25.02 .2020 & $\begin{array}{c}10.03 . \\
2020 \\
\end{array}$ & $\begin{array}{c}28.01 . \\
2020\end{array}$ & $\begin{array}{c}28.01 . \\
2020\end{array}$ & $\begin{array}{c}28.01 . \\
2020\end{array}$ & $\begin{array}{c}28.01 . \\
2020\end{array}$ & + & $\begin{array}{c}30.03 \\
2020\end{array}$ & $\begin{array}{c}12.03 \\
2020 \\
\end{array}$ & $\begin{array}{c}19.03 . \\
2020 \\
\end{array}$ & $\begin{array}{c}19.03 \\
2020\end{array}$ & $\begin{array}{c}16.03 . \\
2020\end{array}$ \\
\hline Rusya & 31.01 .2020 & $\begin{array}{c}14.02 . \\
2020 \\
\end{array}$ & $\begin{array}{c}05.03 . \\
2020 \\
\end{array}$ & $\begin{array}{c}05.03 . \\
2020 \\
\end{array}$ & $\begin{array}{c}05.03 . \\
2020 \\
\end{array}$ & $\begin{array}{c}05.03 . \\
2020 \\
\end{array}$ & - & $\begin{array}{c}23.01 . \\
2020\end{array}$ & $\begin{array}{c}05.03 . \\
2020 \\
\end{array}$ & $\begin{array}{c}06.03 . \\
2020 \\
\end{array}$ & $\begin{array}{c}30.03 . \\
2020\end{array}$ & $\begin{array}{c}25.03 . \\
2020\end{array}$ \\
\hline Malezya & 25.01 .2020 & $\begin{array}{c}08.02 . \\
2020\end{array}$ & $\begin{array}{c}18.03 . \\
2020\end{array}$ & $\begin{array}{c}18.03 . \\
2020\end{array}$ & $\begin{array}{c}18.03 . \\
2020\end{array}$ & $\begin{array}{c}18.03 . \\
2020\end{array}$ & + & $\begin{array}{c}18.03 . \\
2020\end{array}$ & $\begin{array}{c}03.03 . \\
2020\end{array}$ & $\begin{array}{c}18.03 . \\
2020\end{array}$ & $\begin{array}{c}18.03 . \\
2020\end{array}$ & $\begin{array}{c}27.03 . \\
2020\end{array}$ \\
\hline
\end{tabular}


Tablo 4 ve 5 incelendiğinde bu çalışma kapsamında geliştirilen "Pandemide Kriz Yönetimi Kriterleri"ne göre kriterlerin gerçekleşme tarihleri, ülkelerin puanları ve dahil oldukları ekonomik sınıfların ortalamaları görülmektedir. Belirlenen kriterlerin yukarıda da belirtilen sebeplerle kriz başlangıcından itibaren ilk 14 günlük süre içinde gerçekleştirilip gerçekleştirilmediğine göre en yüksek puana Türkiye sahiptir. En düşük puana sahip dört ülke Kanada, Fransa, Rusya ve Malezya'dan oluşmaktadır. Ülkeler puanlara göre sıralandığında ilk dört ülkenin gelişmekte olan ülkelerden olduğu dikkat çekmektedir. Benzer şekilde başlıca gelişmiş ülkelerin puan ortalamaları 37,14 iken, gelişmekte olan ülkeler içinden seçilen yedi ülkenin ortalaması 57,14 olarak hesaplanmıştır. Bir ülke için krizin başlangıcının o ülkedeki ilk resmi vaka olduğu düşünüldügünde ilk 14 günlük sürede kriz yönetimine dair alınan karar ve önlemlere göre gelişmekte olan ülkeler, başlıca gelişmiş ülkelerden daha yüksek "pandemide kriz yönetimi” puanına sahiptir.

Tablo 5. Pandemide Krį Yönetimi Kriterleri Puanlar

\begin{tabular}{|c|c|c|c|c|c|c|c|c|c|c|c|c|c|c|}
\hline \multirow[b]{2}{*}{ Kriter \Ülke } & \multicolumn{7}{|c|}{ Başlıca Gelişmiş Ülkeler } & \multicolumn{7}{|c|}{ Gelişmekte Olan Ülkeler } \\
\hline & $\stackrel{\text { }}{\stackrel{\pi}{\pi}}$ & $\stackrel{\dot{\varphi}}{\dot{q}}$ & 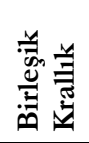 & 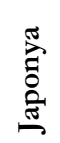 & 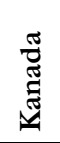 & 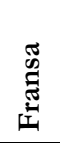 & 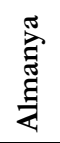 & $\begin{array}{l}\frac{\pi}{2} \\
0 \\
0 \\
0\end{array}$ & 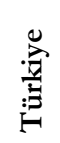 & 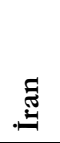 & 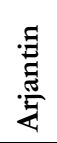 & 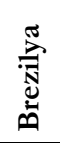 & 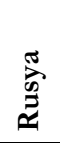 & 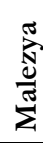 \\
\hline 1 & 10 & 10 & 10 & 10 & 0 & 0 & 0 & 10 & 10 & 10 & 10 & 10 & 0 & 0 \\
\hline 2 & 10 & 10 & 10 & 10 & 0 & 0 & 0 & 10 & 10 & 10 & 10 & 10 & 0 & 0 \\
\hline 3 & 10 & 10 & 10 & 10 & 0 & 0 & 0 & 10 & 10 & 10 & 10 & 10 & 0 & 0 \\
\hline 4 & 10 & 0 & 10 & 10 & 0 & 0 & 0 & 10 & 10 & 10 & 10 & 10 & 0 & 0 \\
\hline 5 & 10 & 10 & 10 & 10 & 10 & 10 & 10 & 10 & 10 & 10 & 10 & 10 & 0 & 10 \\
\hline 6 & 10 & 10 & 10 & 0 & 0 & 0 & 10 & 10 & 10 & 10 & 10 & 0 & 10 & 0 \\
\hline 7 & 0 & 0 & 0 & 0 & 0 & 0 & 0 & 10 & 10 & 10 & 10 & 0 & 0 & 0 \\
\hline 8 & 0 & 0 & 0 & 0 & 0 & 0 & 0 & 0 & 10 & 0 & 10 & 0 & 0 & 0 \\
\hline 9 & 0 & 0 & 0 & 0 & 0 & 0 & 0 & 0 & 10 & 0 & 0 & 0 & 0 & 0 \\
\hline 10 & 0 & 0 & 0 & 0 & 0 & 0 & 0 & 10 & 10 & 0 & 0 & 0 & 0 & 0 \\
\hline \multirow{2}{*}{ Toplam } & 60 & 50 & 60 & 50 & 10 & 10 & 20 & 80 & 100 & 70 & 80 & 50 & 10 & 10 \\
\hline & \multicolumn{7}{|c|}{ Ortalama: 37,14} & \multicolumn{7}{|c|}{ Ortalama: 57,14} \\
\hline
\end{tabular}

Gerek ilk 14 günlük sürede gerekse daha sonraki sürede gerçekleşmiş olsa da tüm ülkelerin ilk 3 kriteri aynı gün gerçekleştirdiği görülmektedir. Diğer kararlar farklı zamanlara yayılmış olsa da kriz yönetim planı, acil eylem planı ve kriz kontrol ve risk takımlarının aynı gün oluşturulduğu ifade edilebilir.

Dikkat çekici bir diğer husus da Rusya hariç tüm ülkelerin ilk 14 günlük süreçte sürekli olarak tüm vatandaşlarına kriz ile ilgili bilgi paylaşımında bulunmasıdır. Ülkelerin tümü tarafından ilk 14 gün içerisinde sağlanmış herhangi bir kriterin olmadığı da göze çarpmaktadır.

\section{Tartışma, Sonuç ve Öneriler}

Bu çalışmanın yapıldığı zaman halen dünya çapında pandemi devam etmekte ve Türkiye'de de dünyada da her geçen gün vaka ve ölüm sayısı artmaktadır. 21 Mayıs 2020 tarihi itibariyle hastalığa yakalananların sayısı 5 milyonu geçmiş ve ölenlerin sayısı da 330 bine yaklaşmıştır. Hastalığın yayılımının ne zaman kontrol altına alınacağı, ne zaman tam bir tedavi ya da önleyici aşı bulunacağı halen belirsizliğini sürdürmektedir (Xu vd., 2020, s. 6). Çalısmanın amacı yukarıda da net bir şekilde belirtildiği gibi hastalığın tıbbi kısmı ya da ölüm ve vaka oranlarına dair istatistikler derlemek değildir. Hastalığa dair verilen bilgiler dünya çapında yaşanan krize tam olarak neyin nasıl sebep olduğunu ortaya koymayı amaçlamaktadır. Covid-19 pandemisi dünya çapında bir paniğe yol açarak tüm sosyal alanları etkilemiş, ekonomiyi sekteye uğratmış, insanlar arası ve özellikle uluslararası etkileşimi neredeyse sıfira düşürmüştür. Böyle bir kriz erken alınan önlemlerle en ucuz şekilde atlatılabilir (Bulduklu ve Karaçor, 2017; Aksu ve Deveci, 2009; Van der Heyden ve Nathanial, 2020). Bu bağlamda oluşturulan araştırma kapsamına göre IMF'nin sınıflamış olduğu Başlıca Gelişmiş Ülkeler ve Gelişmekte Olan Ülkeler literatürdeki bilgilere dayanılarak oluşturulmuş olan "Pandemide Kriz Yönetimi Kriterleri”" açısından değerlendirilmiştir.

İlk 14 günün hem hastalığın bulaşıcılığı hem de salgının yaygınlığının artması açısından kritik bir öneme sahip olduğu bilinmektedir. Ayrıca ekonomik olarak alınan önlemlerin de bu kritik zamana paralel bir şekilde yapılacak olmasının önemi de Van der Heyden ve Nathanial (2020) tarafindan vurgulanmışır. Bilimsel çalışmalara dayanılarak hazırlanmış olan değerlendirme yöntemine göre ülke puanları açısından en 
yüksek puanı Türkiye (100 puan), en düşük puanı ise Kanada, Fransa, Rusya, Malezya (10 puan) almıştır. $\mathrm{Bu}$ çalışma kapsamına göre kriz yönetiminde en başarllı ülkenin açık bir şekilde Türkiye olduğu görülmektedir. Literatürde kriz yönetimine dair yapılması gerekenleri mevcut pandemi durumu da göz önünde bulundurulduğunda dikkate alınan ilk 14 günlük süre açısından tam anlamıyla gerçekleştiren tek ülke Türkiye'dir. Bir puan sıralaması yapıldı̆̆ında; Polonya (80 puan), Arjantin (80 puan) ve İran (70 puan) şeklinde bir sıralama görülmektedir. İncelenen 14 ülkeden en başarılı 4 tanesinin Başlıca Gelissmiş Ülkelerden değil Gelişmekte Olan Ülkelerden olması dikkat çekici bir sonuçtur.

Van der Heyden ve Nathanial (2020) ölüm, vaka gibi sayıların tek başına incelenmesinin yanıltıcı olabileceğinden bahsetmektedir. $\mathrm{Bu}$ açıdan bakıldığında incelenen ülkelerdeki vaka sayısı, ölüm sayısı, iyileşme sayısı gibi bilgiler ve bunlara dair istatistikler kriz yönetiminin doğru gerçekleştirilip gerçekleştirmediğini göstermez. Araştırmaya dair bilgiler toplanırken en çok dikkat çeken bilgilerden birisi Japonya'da sokağa çıkma yasağı getirilmesinin devlet yönetimi tarafindan hakaret olarak algilanmasıdır. Japonya bu kriterden puan alamamasına rağmen Johns Hopkins Üniversitesi verilerine (2020) göre hastalı̆̆In ilk yayılma sürecinde olumlu bir profil çizmiştir. Yukarıda da belirtildiği gibi pandemi süreci halen devam etmekte ve dünyanın bundan tam olarak ne zaman kurtulacağı hala bir muammadır. Diğer bir taraftan ABD, Kanada, Fransa, Rusya, Almanya gibi bazı ülkelerde vaka sayıları ilk 15-20 günlük sürede düşük seviyelerde kalmış ve daha sonra çok daha hızlı bir şekilde yükselmiştir. Her iki açıdan bakıldığında da bir ülke için kriz o ülkedeki ilk vakanın tespiti olarak ele alınmalıdır. Günümüz teknolojisinde iletişim artık saniyeler içinde gerçekleşmekte ve her kişi ya da her kuruluş dünyanın herhangi bir yerinde gerçekleşen bir duruma dair bilgi edinebilmektedir. İlgili ve yetkili kurumlar olayın ciddiyetini, eğer önlem alınmazsa çok daha büyük bir tehdit olabileceğini açıklarken gerekli önlemleri almamak bir ülkenin kriz yönetimini gerçekleştiremediğinin tek göstergesidir.

$\mathrm{Bu}$ çalş̧manın sonuçlarına göre gerekli önlemleri vaktinde alan ve alamayan ülkeler yukarıda değerlendirme kısmında net bir şekilde görülmektedir. IMF ekonomik sınıflandırmalarına göre Başlıca Gelişmiş Ülkelerin ortalama puanları, incelenen Gelişmekte Olan Ülkelerin ortalama puanlarından oldukça düşüktür. Benzer şekilde Başlıca Gelişmiş Ülkelerin İnsani Gelişme Endeksi puanları açısından bakıldığında da benzer bir durum söz konusudur. Puanları Gelişmekte Olan Ülkelere göre daha yüksek olan Başlıca Gelişmiş Ülkeler kriz yönetiminde açık ara daha başarısız olmuştur.

Tablo 4 incelendiğinde belirlenen her kriterin hemen hemen her ülke tarafindan gerçekleştirildiği görülmektedir. Ancak burada önemli olan ne zaman gerçekleştirildiğidir. Dünya çapında bir kriz haline gelen Covid-19 pandemisini ciddiye almayan ya da olayın ciddiyetini ve vahametini daha geç kavrayan kriz yöneticilerinin önlem ve tedbirleri almakta geciktiği aşikardır. Yanlışından dönen ya da önlem almakta geç kalan ülkelerin belirlenen kriterleri eninde sonunda gerçekleştirmesi bu kriterlerin doğru bir şekilde belirlendiğinin en büyük göstergesidir.

Kriz yönetiminin değerlendirmesi amacıyla yapılan bu araştırmada kriz yönetiminin vaktinde alınan kararlarla ve erken önlemlerle gerçekleşip gerçekleşmediği tespit edilmiştir. Yukarıda da net bir şekilde belirtildiği gibi kriz yönetiminin sonuçları olarak ölüm, vaka gibi sayı ve bunlara dair çeşitli istatistikler ele alınmamıştır. Bu gibi verilerin kriz yönetiminin sonuçları arasında olmadığ1 düşünülmektedir. Bunun en büyük sebebi ülkeler arasındaki kültürel farklılıklar, ülkeler arasındaki giriş çıkışın yoğunluğu, ülkelerin turizm potansiyeli ve ziyaretçi sayıları, mevcut hastalığın mevsimsel ve sıcaklığa duyarlı olması gibi birçok farklı faktörün mevcudiyetidir. Daha açı bir ifadeyle kriz yönetiminin başarısı sadece alınan kararlar ve bu kararların zamanı ile ilgilidir. Alınan kararlara, bunların vaktine ve tutarlllığına rağmen hastalı̆̆ı seyri değişiklik gösterebilmektedir. Önemli olan kriz durumunda yapılması gerekenlerin net bir şekilde belirlenmesi ve uygulanmasidır.

Daha sonra yapılacak çalışmalarda mevcut pandemi incelenecek ise kriterlere dair alınan kararların uygulama kısımları ayrıntılı bir şekilde incelenebilir. Teorikte ve pratikte oluşan farklılıklar ya da tutarsızıkların da araştırılması tavsiye edilebilir. Araştırmanın farklı ülkeler ya da farklı sınıflar açısından da gerçekleştirilmesi düşünülebilir. Gerek duyulduğunda kriterlerin eklenip çıarılması da yapılacak araştırmaların kapsamına göre belirlenebilir. Ayrıca bu çalışma kapsamında oluşturulan "Pandemide Kriz Yönetimi Kriterleri”" farklı pandemilerde uygulanabileceği gibi bölgesel salgınlarda daha yerel kriz yöneticilerinin adımları üzerinde de uygulanabilir.

Bu çalışma ile sosyal bilimlerin alanı içinde olmayan bir salgın hastalı̆̆ın yönetim bilimleri açısından değerlendirilmesi gerçekleştirilmiştir. Bu çalş̧ma ile henüz çok güncel bir konu olan pandemide kriz ve kamu yönetimine dair yer alan değerlendirmelerin bilime katkı sağlayabileceği ve daha sonraki çalışmalara 
yol gösterebileceği düşünülmektedir. Ayrıca literatür ve güncel kaynaklar ışığında geliştirilen "Pandemide Kriz Yönetimi Kriterleri’"nin kamu yönetimi ve yönetim bilimleri açısından bilimsel katkı sağlayabileceği düşünülmektedir.

\section{Etik Beyan}

"Koronavirüs (Covnd-19) Pandemisinde Başlca Gelismis Ve Gelişmekte Olan Ülkelerde Kriz. Yönetiminin Değerlendirilmesi" başlıklı çalışmanın yazım sürecinde bilimsel, etik ve alıntı kurallarına uyulmuş; toplanan veriler üzerinde herhangi bir tahrifat yapılmamış ve bu çalışma herhangi başka bir akademik yayın ortamına değerlendirme için gönderilmemiştir.

\section{Kaynakça}

Acar, Y., (2020). Yeni koronavirüs (Covid-19) salgını ve turizm faaliyetlerine etkisi. Güncel Turižn Araștırmalar Dergisi, 4(1), 7-21.

Akdağ, M. ve Arklan, U. (2013). Kamu yönetiminde kriz yönetimi. The Journal of Academic Social Science Studies, 6(4), 3355.

Aksu, A. ve Deveci, S. (2009). İlköğretim okulu müdürlerinin kriz yönetimi becerileri. e-Journal of New World Sciences Academy Education Sciences, 4(2), 448-464.

Aksu, A. (2009). Kriz yönetimi ve vizyoner liderlik. Journal of Yasar University, 4(15), 2435-2450.

Balboni, A., Battilani, M. ve Prosperi, S. (2012). The SARS-like coronaviruses: The role of bats and evolutionary relationships with SARS coronavirus. New Microbiologica, 35, 1-16.

Bulduklu, Y. ve Karaç,or, S. (2017). Sağllk hizmetlerinde kriz iletişimi ve yeni medya. Atatürk İletişim Dergisi, 14(Sağlık Iletişimi Özel Say1), 279-296.

Can, H. (2002). Organizasyon ve Yönetim (6. Baskı). Ankara: Siyasal Kitabevi.

Can, H. (2005). Organizasyon ve Yönetim. Ankara: Siyasal Kitabevi.

Coombs, W. T. (2007). Crisis management and communications. Published by the Institute for Public Relations, December 2007.

Cortegiani, A., Ingoglia, G., Ippolito, M., Giarratano, A. ve Einav, S. (2020). A systematic review on the efficacy and safety of chloroquinefor the treatment of COVID-19. Journal of Critical Care, https://doi.org/10.1016/j.jcrc.2020.03.005

Demirtaş, H. (2000). Kriz yönetimi. Kuram ve Uygulamada Ĕ̈itim Yönetimi, 6(23), 353-373.

Denis, M., Vandeweerd, V., Verbeke, R. ve Van der Vliet, D., (2020). Overview of information available to support the development of medical countermeasures and interventions against COVID-19. https://rega.kuleuven.be/if/corona_covid-19. Transdisciplinary Insights- Living Paper.

Garcia, H. F. (2006). Effective leadership response to crisis. Strategy \& Leadership, 34(1), 4-10.

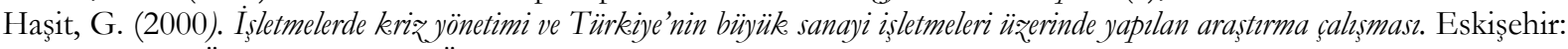
Anadolu Üniversitesi Acık Öğretim Fakültesi Yayınları.

Hittle, B. ve Leonard, K. M. (2011). Decision making in advance of a supply chain crisis. Management Decision, 49(7), 1182-1193.

http://hdr.undp.org/

http://hdr.undp.org/en/content/human-development-report-2019

http://www.legislation.gov.uk/uksi/2020/289/contents/made

http://www.moh.gov.my/index.php/pages/view/2019-ncov-wuhan

http://www.president.ir/en

http://www.salute.gov.it/nuovocoronavirus

https://corona.cbddo.gov.tr/

https://coronavirus.jhu.edu/map.html

https://covid19.saglik.gov.tr/

https://covid19.tubitak.gov.tr/

https://covid19bilgi.saglik.gov.tr/tr/

https://france-visas.gouv.fr/en_US/web/france-visas/professional-internship

https://google.com/covid19-map/?hl=tr

https://hsgm.saglik.gov.tr/tr/covid19

https://konstytucyjny.pl/jerzy-zajadlo-demokracja-deliberatywna-w-pulapce/

https://web.archive.org/web/20200316025200/https://hsgm.saglik.gov.tr/depo/haberler/ncov/2019-

nCov_Hastal_Salk_alanlar_Rehberi.pdf

https://web.archive.org/web/20200330182328/https://covid19bilgi.saglik.gov.tr/depo/afisler/COVID-

19_Kitapcik_A6.pdf

https://www.argentina.gob.ar/salud/coronavirus-COVID-19

https://www.argentina.gob.ar/salud/noticias

https://www.canada.ca/en/public-health/services/diseases/2019-novel-coronavirus-infection.html 
https://www.cas.go.jp/jp/influenza/novel_coronavirus.html

https://www.deutschland.de/en/news/coronavirus-in-germany-informations

https://www.gov.uk/guidance/coronavirus-covid-19-information-for-the-public

https://www.grip.gov.tr/depo/saglik-calisanlari/ulusal_pandemi_plani.pdf

http://hdr.undp.org/sites/default/files/hdr_2019_overview_-_english.pdf

https://www.icisleri.gov.tr/65-yas-ve-ustu-ile-kronik-rahatsizligi-olanlara-sokaga-cikma-yasagi-genelgesi

https://www.mhlw.go.jp/stf/seisakunitsuite/bunya/0000164708_00001.html

https://www.pzh.gov.pl/

https://www.rki.de/DE/Content/InfAZ/N/Neuartiges_Coronavirus/Ergaenzung_Pandemieplan_Covid.pdf?_bl $\mathrm{ob}=$ publicationFile

https://www.ttb.org.tr/haber_goster.php?Guid=bffe89ae-3ea2-11ea-a1a2-6d7c2a5a4754

https://www.un.org/en/sections/about-un/official-languages/index.html

https://www.usa.gov/coronavirus

https://www.weforum.org/agenda/2020/03/covid-responsible-businesses-during-the-coronavirus-pandemic/

https://www.who.int/china/news/detail

https://www.who.int/dg/speeches/detail

https://www.who.int/emergencies/diseases/novel-coronavirus-2019

https://www.who.int/emergencies/diseases/novel-coronavirus-2019

https://www.worldometers.info/coronavirus/

https://xn--80aesfpebagmfblc0a.xn--p1ai/

Kadıbes,egil, S., (2001). Kriz geliyorum der! Kriz Iletişimi ve yönetimi. İstanbul: Mediacat Yayınları.

Korkmazyürek, H. ve Basım, N. (2008). Is modeli ve krizyönetimi. Ankara: Gazi Kitabevi.

Li, X., Zai, J., Wang, X. ve Li, Y. (2020). Potential of large 'first generation' human-to-human transmission of 2019nCoV. Journal of Medical Virology, 92, 448-454.

Longstaff, P. H. ve Yang, S. (2008). Communication management and trust: Their role in building resilience to "surprises" such as natural disasters, pandemic flu, and terrorism. Ecology and Society, 13(1), 3.

Maya, İ. (2014). Kamu ilkokullarında yöneticilerin sergiledikleri kriz yönetimi beceri düzeylerine ilişkin öğretmen görüşleri. Yönetim Bilimleri Dergisi, 12(23), 209-235.

Men, K., Wang, X., Li, Y., Zhang, G., Hu, J., Gao, Y. ve Han, H. (2020). Estimate the incubation period of coronavirus 2019 (COVID-19). medRxiv preprint doi: https://doi.org/10.1101/2020.02.24.20027474.

Mitroff, I. I. (1994). Crisis management and environmentalism: A natural fit. California Management Review, Winter, 101-113.

Narbay, M. Ş. (2005). Kriz. iletişiminde halkla ilişkilerin rolü (Yüksek lisans tezi). Dokuz Eylül Üniversitesi. Sosyal Bilimler Enstitüsü, İzmir.

Nishiura, H., Jung, S. M., Linton, N., Kinoshita, R., Yang, Y., Hayashi, K., Kobayashi, T., Yuan, B. ve Akhmetzhanov, A. R. (2020). The extent of transmission of novel coronavirus in Wuhan, China, 2020. Journal of Clinical Medicine, 9(330), 1-5

Panos, E., Dafni, P., Kostas, G. ve Zacharoula, M., (2009). Crisis management in the health sector; Qualities and characteristics of health crisis managers. International Journal of Caring Sciences, 2(3), 105-107.

Quah, T. R. ve Hin-Peng, L. (2004). Crisis prevention and management during SARS outbreak. Singapore Emerging Infectious Diseases, $10(2), 364-368$.

T.C. SAGLIK BAKANLIGI, 2019-Ncov HASTALIGI SAGLIK C,ALIS,ANLARI REHBERI (Bilim Kurulu Çalışması) OCAK, 2020.

Ul Haq, M. (1989). Human Development Report. United Nations Development Programme.

Van der Heyden, L. ve Nathanial, P. (2020). A Crisis Management Blueprint for COVID-19. https://knowledge.insead.edu/operations/a-crisis-management-blueprint-for-covid-19-13716, April 3, 2020.

Wang, L. F., Shi, Z., Zhang, S., Field, H., Daszak, P. ve Eaton, B. T. (2006). Review of bats and SARS. Emerging Infectious Diseases, 12, 1834.

Xu, j., Zhao, S., Teng, T., Abdalla, A. E., Zhu, W., Xie, L., Wang, Y. ve Guo, X., (2020). Systematic comparison of two animal-to-human transmitted human coronaviruses: SARS-CoV-2 and SARS-CoV. Viruses, 12(244), 1-17.

Zhu, N., Zhang, D., Wang, W., Li, X., Yang, B., Song, J., Zhao, X., Huang, B., Shi, W., Lu, R., Niu, P., Zhan, F., Ma, X., Wang, D., Xu, W., Wu, G., Gao, G. F., Phil, D. ve Tan, W. (2020). A novel coronavirus from patients with pneumonia in China, 2019. The New England Journal of Medicine, 382(8), 727-733.

\section{EXTENDED ABSTRACT}

The COVID-19 is a common human pathogen that is known as common cold and causes minor acute respiratory tract diseases. A number of local health clinics reported some pneumonia cases from a fishery market and seafood wholesaling in Wuhan, Hubei Province of China in the late December, 2019 (Zhu vd., 2020, p. 727; Acar, 2020, p. 8; T.C. Sağlık Bakanllğ1 Covid-19 Rehberi, 2020, p. 5; WHO, Coronavirus Disease (COVID-19) Outbrake, 2020). The temporary name of new coronavirus viral pneumonia outbreak emerged in Wuhan in 9 January 2020 is officially identified as $2019-\mathrm{nCoV}$ (https://www.who.int/china/news/detail). The disease is named as COVID-19, in other terms "SARS- 
CoV-2" by WHO in 11 February 2020 (https://www.who.int/dg/speeches/detail). The disease caused by SARS-CoV-2 is called "coronavirus disease 2019" (COVID-19). WHO declared it as a pandemic in 11 March 2020 and announced that COVID-19 had spread all over the world.

In the literature, some researchers approached the crisis in view of lacking in interference to the circumstances that threatens the existence of entity, society and country; and some other researchers approached it in the perspective of obligation of overcoming the unexpected circumstances (Aksu, 2009, p. 2436). It is certain that crises are so unexpected situations; however, it is inevitable that a difference emerges between those who prepared themselves against the unexpected situation and those did not (Kadıbes,egil, 2003, p. 55). The success in crisis management is directly connected to receiving the signals of crisis promptly and the ability to constitute the necessary precautions (Can, 2002, p. 333). Van der Heyden and Nathanial (2020) state that world leaders fluctuate against this crisis, asserting the number of crises in world history as big as COVID-19 pandemic that we suffer today is extremely slight. The authors categorize the five stages of crisis management, also to be used in COVID-19 crisis with "5E" (Van der Heyden ve Nathanial, 2020):

Stage 1- Engage: Participate in framing the crisis and make the framing right.

Stage 2- Explore: Explore the crisis and how to struggle against it.

Stage 3- Explain: Explain what to decide, why and how to work, then take the action.

Stage 4- Execute: Conduct with focusing and constant monitoring.

Stage 5- Evaluate: Improve, learn and adapt you're strive along with your leadership as you receive new information and feedback.

The purpose of this study is to evaluate the crisis management skills of major advanced economies and some emerging and developing economies during Coronavirus (Covid - 19) which was spread around the world and announced pandemic, that is to say a global disease by WHO on 11 March 2020. In line with this objective, countries' approaches to crisis in the first 14 days beginning from the outbreak were examined and comparison according to IMF economic classification is among study objectives. The onset of crisis is taken as 14 days period after the announcement of first official incidence for each country. The major advanced economies are consisting of Italy, the USA, the UK, Japan, Canada, France, Germany. Although there are more than a hundred emerging and developing economies, seven of them are detected for this study due to their effectiveness in this course. Their ranks in Human Development Index are also taken into consideration while determining the emerging and developing economies of the study.

When this study was conducted, the worldwide pandemic was on going and the number of incidents and deaths was increasing everyday both in Turkey and the world. The number of afflicted to disease were almost 1,5 million and death toll was more than 85 thousands. When to take the spread of disease under control and to find a cure or vaccine are still uncertain (Xu et. al., 2020, p. 6).

It's certain that the first 14 days have a critical importance in terms of both the transmission of disease and the rise of pandemic extensiveness. Moreover the importance of taking economic measures during this critical period is emphasised by Van der Heyden and Nathanial (2020). According to evaluation method prepared by scientific studies, Turkey had the highest score (100), while Canada, France, Russia, and Malaysia got the lowest (10). Within the scope of this study, it can be seen that the most successful country in crisis management is explicitly Turkey.

According to IMF economic classification, the average scores of major advanced economies are relatively lower than emerging and developing economies that were analysed. Likewise, the results are similar for advanced economies when Human Development Index scores are considered. Major advanced economies that have much more higher scores than emerging and developing countries were significantly less successful.

It's thought that the evaluation for crisis management and public administration for pandemic -which is a trending issue- may contribute to science and guide later studies with this study. In addition, "Crisis Management Criteria in Pandemic" which was formed in the view of literature and up-to-date sources can also provide scientific contribution in terms of public administration and management sciences. 